\title{
Life Satisfaction and Extra-curricular Activities among Medical Students at Ain Shams University
}

\author{
Hebat-Allah M.S. Gabal, Dina N.K. Boulos
}

Department of Community, Environmental and Occupational Medicine, Faculty of Medicine, Ain Shams University, Cairo, Egypt

\begin{abstract}
Background: A full understanding of life satisfaction (LS) and extracurricular activities (EAs) participation prevalence and reported participation barriers is imperative to successfully enhance and support the mental well-being and academic achievement of medical students. Objectives: To measure the level of life satisfaction using The Multidimensional Students' Life Satisfaction Scale (MSLSS), to measure the percentage of students participating in EAs among medical students at Ain Shams University, and to identify the relationship between LS, EAs, and academic achievement among the studied group. Method: a cross-sectional study was applied on a sample of 240 students using a self-administered questionnaire including socio-demographic data, faculty related data including average grade, data related to EAs participation and the MSLSS. Results: Mean life satisfaction score among the studied sample was $4.0 \pm 0.73$. Participation in EAs was reported by $42.9 \%$ of students, the most frequently reported EAs $(73.8 \%)$ was volunteering in health awareness campaigns. Multiple linear regression analysis revealed that female gender, living alone, being physically active, spending less free time on the internet not for studying purpose, spending more time with family and in studying explain about $15 \%$ of the variation in life satisfaction $\left(\mathrm{R}^{2}=0.149\right.$, $\mathrm{F}=2.43, \mathrm{P}<0.01)$ Conclusion and Recommendations: Designing interventions to encourage students to increase their physical activity and to spend less free time surfing the internet to promote life satisfaction. Furthermore, integrating EAs in the medical curriculum to boost the students' quality of life, personal development, future career, and mental health.
\end{abstract}

Keywords: Extracurricular activities, Life Satisfaction, Medical Students, Multidimensional Students' Life Satisfaction Scale.

Corresponding author:_Hebat-Allah Mohammed Salah Gabal Email: Babosha2008@yahoo.com

\section{Introduction}

Subjective well-being (SWB) has become a central area of inquiry. ${ }^{1}$ Often believed to be informally equal to happiness, SWB has been defined as "a higher-order construct that incorporates three related, but distinguishable lower-order constructs of global life satisfaction (LS), positive, and negative affect" .

Life satisfaction is an overall evaluation of a person's feelings and attitudes about own Table (1): Study participant's characteristics $(n=240)$ life at a specified point in his lifetime. ${ }^{3}$ Simply, it means how much a person likes his life. ${ }^{4}$ It has also been described as an individual's well-being and opinion regarding current life and aims for the future .

The global life satisfaction depends upon how an individual assesses different life domains including five main domains concerning satisfaction with friends, 
Hebat-Allah M.S. Gabal, et al Life Satisfaction and Extra-curricular Activities among Medical 66

\begin{tabular}{|c|c|c|c|}
\hline \multicolumn{2}{|c|}{ Characteristic } & \multirow{2}{*}{$\begin{array}{c}\mathbf{N} \\
19.53 \pm 1.41\end{array}$} & \multirow{2}{*}{$\begin{array}{l}\% \\
(17-23)\end{array}$} \\
\hline Age & mean \pm SD $(\min -\max )$ & & \\
\hline \multirow[t]{2}{*}{ Gender } & Male & 91 & 37.9 \\
\hline & Female & 149 & 62.1 \\
\hline \multirow[t]{2}{*}{ Academic year } & Pre-clinical & 125 & 52.1 \\
\hline & Clinical & 115 & 47.9 \\
\hline \multirow[t]{5}{*}{ Living with whom } & Parents & 203 & 84.6 \\
\hline & Relatives & 17 & 7.1 \\
\hline & Friends & 10 & 4.2 \\
\hline & Alone & 7 & 2.9 \\
\hline & Others & 3 & 1.3 \\
\hline \multirow[t]{4}{*}{ Average grade in faculty } & Excellent & 97 & 40.4 \\
\hline & Very Good & 87 & 36.3 \\
\hline & Good & 43 & 17.9 \\
\hline & Acceptable & 13 & 5.4 \\
\hline \multirow[t]{6}{*}{ Activities practiced during free time ${ }^{\#}$} & Surfing the Interne & 208 & 86.7 \\
\hline & Reading books & 103 & 42.9 \\
\hline & Sports & 95 & 39.6 \\
\hline & Shopping & 55 & 22.9 \\
\hline & Playing with friends & 97 & 40.4 \\
\hline & Other * & 51 & 21.2 \\
\hline Days per week spent in faculty & mean \pm SD $(\min -\max )$ & $4.0 \pm 1.0$ & $(2-6)$ \\
\hline Hours per day spent in faculty & mean \pm SD $(\min -\max )$ & $6.0 \pm 2.0$ & $(3-10)$ \\
\hline Studying hours per day & mean \pm SD $(\min -\max )$ & $4.0 \pm 2.0$ & $(0-12)$ \\
\hline $\begin{array}{l}\text { Hours per day spent in surfing the Int } \\
\text { studying purpose }\end{array}$ & $\begin{array}{l}\text { ernet time freely not for a } \\
\text { mean } \pm \text { SD }(\min -\max )\end{array}$ & $3.1 \pm 1.6$ & $(0-8)$ \\
\hline
\end{tabular}

family, school, self, and living environment. Consistent LS through time from childhood to adolescence has been found by different researches. SWB has been linked to desirable results and consequences across multiple life domains, including career success. The research suggests a fundamental relationship between LS and several key school outcomes, high levels of LS are connected to high academic efficacy, positive socioeconomic status. ${ }^{6,7,8,9}$

A study conducted among a sample of Canadian university students concluded that there is a positive relationship between LS and self-reported GPA. Rode et al. (2005) found a positive correlation between LS and self-reported GPA among college students, even after the control of covariates (cognitive aptitude and demographic characters). Similarly, middle and high school adolescent students with high or average levels of LS achieved higher self-reported GPA than those with low levels of LS. ${ }^{10-12}$

Huebner in 1994 designed the Multidimensional Students Life Satisfaction Scale (MSLSS) as a tool to portray a multidimensional profile of life satisfaction in five domains (family, studies, friends, neighborhood, and self) as well as to assess the overall life satisfaction. $^{13}$ 
Table (2): Description of Extracurricular activities among study participants (n=240):

\begin{tabular}{|c|c|c|c|}
\hline \multirow{3}{*}{ Extra-curricular activities } & & $\mathbf{N}$ & $\%$ \\
\hline & No & 137 & 57.1 \\
\hline & Yes & 103 & 42.9 \\
\hline \multirow[t]{2}{*}{ Site of Extra-curricular activities participation ${ }^{\&}$} & Inside campus & 82 & 79.6 \\
\hline & Outside campus & 68 & 66.0 \\
\hline \multirow[t]{4}{*}{ Different Types of Extra-curricular Activities ${ }^{\&}$} & Volunteering* & 76 & 73.8 \\
\hline & Sports & 21 & 20.4 \\
\hline & Artistic & 12 & 11.7 \\
\hline & Peer tutoring & 3 & 2.9 \\
\hline \multirow{5}{*}{$\begin{array}{l}\text { Causes of not participating in Extra-curricular } \\
\text { activities \& }\end{array}$} & Lack of time & 97 & 70.8 \\
\hline & Far from home & 76 & 55.5 \\
\hline & Not interested & 75 & 54.7 \\
\hline & Expensive & 31 & 22.6 \\
\hline & Others\# & 12 & 8.8 \\
\hline \multicolumn{4}{|c|}{ Opinion of students as regards Extra-curricular activities: } \\
\hline \multirow{2}{*}{$\begin{array}{l}\text { Studying medicine affect Extra-curricular } \\
\text { activities participation }\end{array}$} & No & 39 & 16.2 \\
\hline & Yes & 201 & 83.8 \\
\hline \multirow{3}{*}{$\begin{array}{l}\text { What is the effect of Extra-curricular activities } \\
\text { participation on your grade? }\end{array}$} & It decreases my grade & 83 & 34.6 \\
\hline & It increases my grade & 47 & 19.6 \\
\hline & It has no effect & 110 & 45.8 \\
\hline \multirow[t]{5}{*}{$\begin{array}{l}\text { How studying medicine affect your ability to } \\
\text { participate in Extra-curricular activities? }\end{array}$} & $\begin{array}{l}\text { It consumes physical } \\
\text { ability }\end{array}$ & 98 & 40.8 \\
\hline & It consumes all the time & 139 & 57.9 \\
\hline & It causes depression & 95 & 39.6 \\
\hline & $\begin{array}{l}\text { It decreases } \\
\text { participation }\end{array}$ & 109 & 45.4 \\
\hline & $\begin{array}{l}\text { It increases } \\
\text { participation }\end{array}$ & 8 & 3.3 \\
\hline
\end{tabular}

* volunteering for service in health awareness and campaign \#depressed and has no relation with them \& multiple responses were accepted

Extracurricular activities (EAs) are defined as "the nonacademic and nonmandatory activities that are undertaken by students and fall outside the domain of the medical school curriculum." Students participate in these EAs either inside or outside the campus. The most common examples are peer tutoring, convoys, community service, volunteering services, social, cultural, religious, and sports activities. ${ }^{14-15}$ Many researchers have revealed that participating in EAs and volunteering help students to cope with stress and ensure a better balance of their life, in addition to increasing leadership capacity, critical thinking, social selfconfidence, and conflict resolution skills. $^{14,16-18}$ Moreover, some studies showed a positive association of EAs participation with academic achievement. $^{19,21}$

A full understanding of LS and EAs participation prevalence and reported participation barriers is imperative to successfully promote and aid the mental well-being and academic achievement of medical students. and to plan necessary changes within the medical education programs. Available data on LS is scarce and the relationship between LS, EAs, and academic achievement among medical students. To the best of our knowledge, this is the first study in Egypt to address this gap 
Table (3): Comparison between high school and during faculty free time, family time and participation in Extracurricular activities $(n=240)$ :

\begin{tabular}{|c|c|c|c|}
\hline \multicolumn{3}{|c|}{ Characteristic } & P-value \\
\hline \multicolumn{4}{|c|}{ Comparison between Free Time during high School and during faculty } \\
\hline \multicolumn{3}{|c|}{$\begin{array}{l}\text { Average no of hours of free time per week in high school } \\
\text { mean } \pm \text { SD }\end{array}$} & \\
\hline \multicolumn{2}{|c|}{$\begin{array}{l}\text { Average no of hours of free time per week in faculty } \\
\text { mean } \pm \text { SD }\end{array}$} & $13.26 \pm 10.20$ & $<0.001 *$ \\
\hline \multicolumn{4}{|c|}{ Family time during high School and during the faculty } \\
\hline \multicolumn{3}{|c|}{$\begin{array}{l}\text { Average no of hours spent with family per week during high school } \\
\text { mean }\end{array}$} & \\
\hline \multicolumn{3}{|c|}{ Average no of hours spent with family per week during faculty } & $<0.001 *$ \\
\hline \multicolumn{4}{|c|}{ Comparison between participation in Extra- curricular during high School and during faculty } \\
\hline \multirow{2}{*}{$\begin{array}{l}\text { Participation in Extra- curricular } \\
\text { activities during faculty }\end{array}$} & \multicolumn{2}{|c|}{$\begin{array}{c}\text { Participation in Extracurricular activities } \\
\text { during high school }\end{array}$} & P-value \\
\hline & $\begin{array}{c}\text { Yes } \\
\mathbf{N}(\%)\end{array}$ & $\begin{array}{c}\text { No } \\
\mathbf{N}(\%) \\
\end{array}$ & \\
\hline Yes & $36(15.0)$ & $66(27.5)$ & \\
\hline No & $37(15.4)$ & $101(42.1)$ & $<0.001 * *$ \\
\hline \multicolumn{4}{|c|}{ Comparison between visiting relatives during high School and during faculty } \\
\hline Characteristic & $\begin{array}{c}\text { During high } \\
\text { school } \\
\text { N }(\%)\end{array}$ & $\begin{array}{c}\text { During faculty } \\
\qquad \mathbf{N}(\%)\end{array}$ & P-value \\
\hline More than once a week & $34(14.2)$ & $9(3.8)$ & \\
\hline Once a week & $74(30.8)$ & $26(10.8)$ & \\
\hline Once a month & $46(19.2)$ & $41(17.1)$ & \\
\hline Once a year & $17(7.1)$ & $34(14.2)$ & $<0.001^{+}$ \\
\hline In occasions only & $58(24.2)$ & $116(48.3)$ & \\
\hline Others & $11(4.6)$ & $14(5.8)$ & \\
\hline
\end{tabular}

* Paired t-test ** Mc-Nemar test \# for Marginal homogeneity test

of knowledge. The current research aims to measure the level of life satisfaction using MSLSS, to measure the percentage of students participating in EAs, among medical students at Ain Shams University, and to identify the relationship between LS, EAs, and academic achievement among the studied group.

\section{Method}

A cross-sectional study design was used to collect data from medical students at Ain Shams University for one month after the midyear vacation in 2020. Faculty of Medicine, Ain Shams University was established in 1947. In 2018-19 the faculty started offering a fully integrated modularbased 5 years medical education replacing the previous classic 6 years disciplinebased curriculum.

Students of Faculty of Medicine Ain shams University excluding ${ }^{\text {st }}$ year students were included. At the Faculty of Medicine Ain Shams University, the Bachelor of Medicine and Surgery program is divided into two major phases: a pre-clinical phase involving the first three years and a clinical phase which includes the last three years in the classic discipline-based program and the last two years in the new fully integrated modular program. First-year students were 
Table (4): Factors affecting life satisfaction among study participants(n=240):

\begin{tabular}{|c|c|c|c|c|c|c|c|}
\hline \multirow{2}{*}{\multicolumn{2}{|c|}{ Characteristic }} & \multicolumn{6}{|c|}{ Life satisfaction } \\
\hline & & $\begin{array}{c}\begin{array}{c}\text { Overall } \\
\text { score }\end{array} \\
\end{array}$ & $\begin{array}{c}\text { Friend } \\
\text { domain }\end{array}$ & \multirow{2}{*}{$\begin{array}{c}\begin{array}{c}\text { Family } \\
\text { domain }\end{array} \\
\text { mean } \pm \text { sd } \\
\end{array}$} & \multirow{2}{*}{$\begin{array}{c}\begin{array}{c}\text { Collage } \\
\text { domain }\end{array} \\
\text { mean } \pm \text { sd } \\
\end{array}$} & \multirow{2}{*}{$\begin{array}{c}\begin{array}{c}\text { Living } \\
\text { domain }\end{array} \\
\text { mean } \pm \text { sd } \\
\end{array}$} & $\begin{array}{c}\begin{array}{c}\text { Self } \\
\text { domain }\end{array} \\
\end{array}$ \\
\hline & & mean \pm sd & mean \pm sd & & & & mean \pm sd \\
\hline mean $\pm \mathrm{SD}$ & & $4.0 \pm 0.73$ & $4.41 \pm 0.89$ & $4.30 \pm 1.29$ & $3.59 \pm .94$ & $3.72 \pm 0.78$ & $4.02 \pm 1.12$ \\
\hline range & & $2.05-5.33$ & $2.0-6.0$ & $1.0-6.0$ & $1.1-6.0$ & $1.44-5.67$ & $1.14-6.0$ \\
\hline & $<19$ & $4.04 \pm 0.74$ & $4.34 \pm 0.94$ & $4.24 \pm 1.23$ & $3.80 \pm 0.92$ & $3.79 \pm 0.83$ & $4.04 \pm 1.03$ \\
\hline & $>=19$ & $3.99 \pm 0.73$ & $4.43 \pm 0.88$ & $4.32 \pm 1.13$ & $3.53 \pm 0.94$ & $3.70 \pm 0.76$ & $4.01 \pm 1.15$ \\
\hline p-value* & & 0.69 & 0.48 & 0.69 & 0.06 & 0.42 & 0.87 \\
\hline \multirow{2}{*}{ Gender } & Male & $3.88 \pm 0.73$ & $4.19 \pm 0.87$ & $4.03 \pm 1.29$ & $3.61 \pm 0.86$ & $3.67 \pm 0.84$ & $3.93 \pm 1.08$ \\
\hline & Female & $4.08 \pm 0.72$ & $4.54 \pm 0.89$ & $4.47 \pm 1.27$ & $3.58 \pm 0.99$ & $3.75 \pm 0.74$ & $4.07 \pm 1.15$ \\
\hline p-value * & & 0.04 & $<0.001$ & 0.01 & 0.82 & 0.39 & 0.32 \\
\hline \multirow{2}{*}{$\begin{array}{l}\text { Academic } \\
\text { year }\end{array}$} & Pre-clinical & $4.03 \pm 0.72$ & $4.51 \pm 0.92$ & $4.29 \pm 1.22$ & $3.59 \pm 0.96$ & $3.74 \pm 0.83$ & $4.02 \pm 1.11$ \\
\hline & Clinical & $3.99 \pm 0.75$ & $4.30 \pm 0.85$ & $4.32 \pm 1.37$ & $3.61 \pm 0.93$ & $3.70 \pm 0.72$ & $4.02 \pm 1.14$ \\
\hline p-value* & & 0.97 & 0.05 & 0.86 & 0.87 & 0.63 & 0.99 \\
\hline \multirow{5}{*}{$\begin{array}{l}\text { Living } \\
\text { whom }\end{array}$} & nts & $3.98 \pm 0.74$ & $4.41 \pm 0.93$ & $4.26 \pm 1.30$ & $3.56 \pm 0.92$ & $3.72 \pm 0.77$ & $3.98 \pm 1.13$ \\
\hline & Relatives & $4.07 \pm 0.76$ & $4.54 \pm 0.82$ & $4.56 \pm 1.31$ & $3.49 \pm 1.03$ & $3.72 \pm 0.92$ & $4.03 \pm 0.94$ \\
\hline & Friends & $3.99 \pm 0.74$ & $4.04 \pm 0.43$ & $4.31 \pm 1.54$ & $3.96 \pm 1.13$ & $3.78 \pm 0.69$ & $3.83 \pm 1.22$ \\
\hline & Alone & $4.49 \pm 0.38$ & $4.51 \pm 0.70$ & $4.69 \pm 0.75$ & $4.09 \pm 0.94$ & $4.06 \pm 0.79$ & $5.10 \pm 0.71$ \\
\hline & Others & $4.26 \pm 0.20$ & $4.70 \pm 0.63$ & $4.67 \pm 0.36$ & $4.42 \pm 0.59$ & $2.85 \pm 0.97$ & $4.67 \pm 0.58$ \\
\hline \multicolumn{2}{|l|}{ p-value ** } & 0.45 & 0.65 & 0.78 & 0.18 & 0.27 & 0.08 \\
\hline \multirow{4}{*}{ Average grade } & Excellent & $4.01 \pm 0.74$ & $4.45 \pm 0.89$ & $4.32 \pm 1.30$ & $3.55 \pm 0.95$ & $3.74 \pm 0.73$ & $3.97 \pm 1.12$ \\
\hline & Very Good & $3.97 \pm 0.70$ & $4.42 \pm 0.90$ & $4.17 \pm 1.25$ & $3.61 \pm 1.00$ & $3.68 \pm 0.75$ & $3.97 \pm 1.09$ \\
\hline & Good & $4.04 \pm 0.81$ & $4.27 \pm 0.89$ & $4.46 \pm 1.42$ & $3.65 \pm 0.91$ & $3.73 \pm 0.88$ & $4.08 \pm 1.19$ \\
\hline & Acceptable & $4.18 \pm 0.69$ & $4.44 \pm 1.00$ & $4.57 \pm 1.12$ & $3.60 \pm 0.71$ & $3.80 \pm 1.07$ & $4.46 \pm 1.15$ \\
\hline p-value*** & & 0.81 & 0.74 & 0.53 & 0.95 & 0.93 & 0.45 \\
\hline \multirow{2}{*}{$\begin{array}{l}\text { Participation } \\
\text { in extra } \\
\text { curricular } \\
\text { activities }\end{array}$} & No & $3.98 \pm 0.77$ & $4.42 \pm 0.98$ & $4.27 \pm 1.34$ & $3.54 \pm 0.96$ & $3.74 \pm 0.85$ & $3.93 \pm 1.13$ \\
\hline & Yes & $4.05 \pm 0.68$ & $4.39 \pm 0.77$ & $4.35 \pm 1.24$ & $3.66 \pm 0.92$ & $3.70 \pm 0.68$ & $4.14 \pm 1.10$ \\
\hline \multicolumn{2}{|l|}{ p-value* } & 0.46 & 0.79 & 0.64 & 0.33 & 0.73 & 0.14 \\
\hline \multirow{2}{*}{$\begin{array}{l}\text { Physical } \\
\text { Activity }\end{array}$} & No & $3.92 \pm 0.74$ & $4.34 \pm 0.92$ & $4.19 \pm 1.32$ & $3.48 \pm 0.95$ & $3.69 \pm 0.75$ & $3.93 \pm 1.13$ \\
\hline & Yes & $4.18 \pm 0.68$ & $4.54 \pm 0.84$ & $4.52 \pm 1.20$ & $3.84 \pm 0.89$ & $3.79 \pm 0.83$ & $4.21 \pm 1.08$ \\
\hline p-value* & & 0.01 & 0.10 & 0.05 & $<0.001$ & 0.35 & 0.06 \\
\hline
\end{tabular}

excluded because as freshmen, they were still in the process of settling down and adjusting to the faculty experience. Consequently, they might not fully engage in EAs especially inside the campus in addition to not having a history of academic achievement within the faculty Pass program was used to calculate sample size yielding a sample of 196 students by setting the type- 1 error $(\alpha)$ at 0.05 with a distance from the mean to the confidence limits equal to 0.08. Results from a previous study (Corea et al., 2017) $)^{22}$ showed that the mean overall satisfaction among participants was $4.62 \pm 0.57$. The present study included 240 students to take into account drop out and incomplete responses. Convenience sampling was used, students were requested to fill the questionnaire during their break and participation was entirely voluntary. 
Anonymous, self-administered questionnaire was used; the questionnaire included four sections: Section 1: covering

Table (5) Factors affecting participation in Extracurricular activities among studied sample $(\mathbf{n}=\mathbf{2 4 0})$ :

\begin{tabular}{|c|c|c|c|c|}
\hline \multirow{2}{*}{\multicolumn{2}{|c|}{ Characteristic }} & \multicolumn{2}{|c|}{ Social Activity } & \multirow[b]{2}{*}{ p-value } \\
\hline & & \multirow{2}{*}{$\begin{array}{c}\text { No } \\
\mathbf{N}(\%) \\
19.23(1.34)\end{array}$} & \multirow{2}{*}{$\begin{array}{c}\text { Yes } \\
\mathbf{N}(\%) \\
19.92(1.41)\end{array}$} & \\
\hline Age & Mean (sd) & & & $<0.001 *$ \\
\hline \multirow{2}{*}{ Gender } & Male & $45(32.8)$ & $46(44.7)$ & \multirow{2}{*}{$0.06 * *$} \\
\hline & Female & $92(67.2)$ & $57(55.3)$ & \\
\hline \multirow{2}{*}{ Academic year } & Academic years $^{\#}$ & $86(62.8)$ & $39(37.9)$ & \multirow{2}{*}{$<0.001 * *$} \\
\hline & Practical years & $51(37.2)$ & $64(62.1)$ & \\
\hline \multirow{4}{*}{ Average grade } & Excellent & $54(39.4)$ & $43(41.7)$ & \multirow{4}{*}{$0.13 * *$} \\
\hline & Very Good & $44(32.1)$ & $43(41.7)$ & \\
\hline & Good & $31(22.6)$ & $12(11.7)$ & \\
\hline & Acceptable & $8(5.8)$ & $5(4.9)$ & \\
\hline \multirow[t]{5}{*}{ Live with whom } & Parents & $119(86.9)$ & $84(81.6)$ & \multirow{5}{*}{$0.77 * *$} \\
\hline & Relatives & $9(6.6)$ & $8(7.8)$ & \\
\hline & Friends & $5(3.6)$ & $5(4.9)$ & \\
\hline & Alone & $3(2.2)$ & $4(3.9)$ & \\
\hline & Others & $1(33.3)$ & $2(1.9)$ & \\
\hline \multirow{2}{*}{ Physical Activity } & No & $97(70.8)$ & $64(62.1)$ & \multirow{2}{*}{$0.16 * *$} \\
\hline & Yes & $40(29.2)$ & 39 (37.9) & \\
\hline Days per week spent in faculty & Mean \pm sd & $4.49 \pm 0.77$ & $4.43 \pm 0.89$ & $0.56^{*}$ \\
\hline Hours per day spent in faculty & Mean \pm sd & $5.77 \pm 1.63$ & $6.63 \pm 1.64$ & $0.52 *$ \\
\hline Studying hours per day & Mean \pm sd & $4.19 \pm 1.89$ & $3.71 \pm 1.85$ & $0.05 *$ \\
\hline \multicolumn{2}{|c|}{$\begin{array}{l}\text { Average no of hours of free time per week in faculty } \\
\text { Mean } \pm \text { sd }\end{array}$} & $13.04 \pm 9.33$ & $13.58 \pm 11.31$ & $0.68 *$ \\
\hline \multicolumn{2}{|c|}{$\begin{array}{l}\text { average no of hours spent with family during faculty } \\
\text { Mean } \pm \text { sd }\end{array}$} & $7.74 \pm 8.59$ & $7.83 \pm 8.16$ & $0.93 *$ \\
\hline \multicolumn{2}{|c|}{$\begin{array}{l}\text { Hours per day spent in surfing the Internet time freely } \\
\text { not for a studying purpose } \\
\text { Mean } \pm \text { sd }\end{array}$} & $2.69 \pm 1.58$ & $3.31 \pm 1.77$ & $0.10 *$ \\
\hline
\end{tabular}

* independent $t$-test $* *$ chi square \# reference group

Socio-demographic data (e.g. age, gender, residence ...etc.). Section 2: containing data related to the faculty including average grade, time spent in the faculty per week, studying time. Section 3: included questions on average time (hours per week) spent with family and frequency of visiting relatives during high school and faculty. As well as questions on participation in EAs, the frequency, type, and perception of EAs influence on academic achievement and EAs participation barriers. Extracurricular activities were defined as any activity not related to the studied curriculum either performed inside or outside the campus e.g. volunteer/community services, awareness convoys, sports, arts, and cultural activities.

Section4: The Multidimensional Students' Life Satisfaction Scale (MSLSS; Huebner, 1994) is a 40-item instrument used for adolescents to measure overall life satisfaction and satisfaction across five domains including family, friends, school, living environment, and self. ${ }^{13}$ MSLSS was validated to be used among university students by different studies and showed adequate psychometric behavior in this kind of population. ${ }^{22-24}$ The Family domain points to the individuals' satisfaction with their relationship with family members and the family members' relationships with each other. 
The school domain investigates the participants' satisfaction with school life

including interest, learning, and educational

Table (6): Linear regression analysis for factors affecting life satisfaction among studied sample(n=240):

\begin{tabular}{|c|c|c|c|c|c|c|c|}
\hline \multirow{2}{*}{ Variables } & \multicolumn{2}{|c|}{$\begin{array}{c}\text { Un-standardized } \\
\text { Coefficients } \\
\end{array}$} & \multirow{2}{*}{$\begin{array}{c}\begin{array}{c}\text { Standardized } \\
\text { Coefficients }\end{array} \\
\text { Beta }\end{array}$} & \multirow{2}{*}{ t-test } & \multirow{2}{*}{ Sig. } & \multicolumn{2}{|c|}{$\begin{array}{c}\text { 95.0\% Confidence } \\
\text { Interval for B } \\
\end{array}$} \\
\hline & B & Std. Error & & & & $\begin{array}{l}\text { Lower } \\
\text { Bound }\end{array}$ & $\begin{array}{l}\text { Upper } \\
\text { Bound }\end{array}$ \\
\hline Constant & 4.20 & 0.75 & $\begin{array}{ll}--- \\
\end{array}$ & 5.60 & 0.00 & 2.72 & 5.68 \\
\hline Age & -0.03 & 0.04 & -0.07 & -0.94 & 0.35 & -0.11 & 0.04 \\
\hline Female sex & 0.27 & 0.10 & 0.18 & 2.69 & 0.01 & 0.07 & 0.46 \\
\hline \multicolumn{8}{|l|}{ Living with whom* } \\
\hline Relatives & 0.21 & 0.19 & 0.07 & 1.13 & 0.26 & -0.16 & 0.57 \\
\hline Friends & 0.15 & 0.25 & 0.04 & 0.59 & 0.56 & -0.35 & 0.64 \\
\hline Alone & 0.57 & 0.29 & 0.13 & 2.00 & 0.05 & 0.01 & 1.13 \\
\hline Other & 0.25 & 0.42 & 0.04 & 0.59 & 0.56 & -0.58 & 1.08 \\
\hline \multicolumn{8}{|l|}{ Average grade*** } \\
\hline$\overline{\text { Very good }}$ & -0.12 & 0.22 & -0.08 & -0.56 & 0.58 & -0.55 & 0.31 \\
\hline Good & -0.02 & 0.23 & -0.01 & -0.10 & 0.92 & -0.48 & 0.43 \\
\hline Excellent & -0.19 & 0.22 & -0.13 & -0.89 & 0.38 & -0.62 & 0.23 \\
\hline $\begin{array}{l}\text { Extra- curricular } \\
\text { activities } \\
\text { participation }\end{array}$ & 0.15 & 0.10 & 0.10 & 1.52 & 0.13 & -0.05 & 0.34 \\
\hline Physically active & 0.25 & 0.10 & 0.16 & 2.53 & 0.01 & 0.06 & 0.44 \\
\hline Internet free time & -0.08 & 0.03 & -0.17 & -2.67 & 0.01 & -0.13 & -0.02 \\
\hline Free time in faculty & 0.00 & 0.01 & 0.03 & 0.39 & 0.70 & -0.01 & 0.01 \\
\hline Family time in faculty & 0.01 & 0.01 & 0.16 & 2.27 & 0.02 & 0.00 & 0.03 \\
\hline $\begin{array}{l}\text { Hours per day in } \\
\text { faculty }\end{array}$ & -0.03 & 0.03 & -0.06 & -0.86 & 0.39 & -0.08 & 0.03 \\
\hline $\begin{array}{l}\begin{array}{l}\text { Studying hours per } \\
\text { day }\end{array} \\
\end{array}$ & 0.06 & 0.03 & 0.15 & 2.23 & 0.03 & 0.01 & 0.11 \\
\hline
\end{tabular}

*Reference group is living with parents** Reference group is acceptable

activities. Peer adolescent 'satisfaction is described by the friend's domain. The selfdomain provides the respondent's level of satisfaction with himself or herself and other people's opinions in this regard. Finally, to explore the satisfaction with the immediate community and other people within the respondents' neighborhood, the living environment domain was used. ${ }^{25}$ The responses were provided using a sixpoint Likert-type scale, ranging from completely disagree to completely agree. Acceptable psychometric properties of MSLSS were proved, including stability coefficients, strong evidence of construct validity as indicated by both confirmatory and exploratory factor analyses, and robust evidence for convergent and discriminant validity. ${ }^{26}$ Stable reliability was proved and ranged between 0.70 and 0.90 in test-retest applications. $^{27}$ The scale shows Cronbach's alpha coefficients between 0.90 and 0.92 for the global scale and 0.72 and 0.85 for the particular domains. ${ }^{26,28}$ The domain, and the total score are obtained by adding the responses and dividing by the number of items in each domain or the total number to obtain the overall assessment 27,28

A pilot study was applied to $10 \%$ of the sample. The purpose was to establish the clarity and relevance of the tools. Besides, it helped to estimate the time required for filling the questionnaire. Based on pilot study results no modifications were required. Pilot data were excluded from the 
study results. The reliability of the studied scale by Cronbach's alpha was examined for the global scale and it was 0.90, therefore the scale reliability was fully acceptable.

\section{Ethical Consideration}

Ethical approval from the Research Ethical Committee of Faculty of Medicine, Ain Shams University was obtained. Informed consent was obtained, and confidentiality of data was guaranteed to all participants.

\section{Data management and analysis}

The collected data were revised, coded, and entered on a computer. SPSS package version 20 was used for the analysis. The description of quantitative data was done as mean, standard deviation (SD), and range values. To compare quantitative variables between groups; an independent t-test and ANOVA were used. Qualitative data were expressed as frequencies (n) and percentage (\%). To test the association between qualitative variables, Chi-square was used. McNemar and marginal homogeneity tests were used to compare paired observations. Correlation between different variables was done by The Pearson correlation coefficient. A correlation was considered low when $r$ was between 0.10 to 0.29 , moderate when $\mathrm{r}$ was between 0.30 and 0.49 , and high when $\mathrm{r}$ was between 0.50 and 1.0. ${ }^{29}$ The level of significance was set at $\mathrm{p}$-value $\leq 0.05$.

\section{Results}

The current study included 240 medical students from ASU; the mean age was $19.5 \pm 1.4$ years. Females constituted $(62.1 \%)$ of the studied sample, $(52.1 \%)$ in the pre-clinical phase. Most of the studied students live with their parents $(84.6 \%)$ and the vast majority have achieved high grades. The mean number of hours spent in the faculty per day was $6.0 \pm 2.0$ and the mean number of days per week was 4.0 1 1.0. The most frequently reported free time activities by the study participants were surfing the internet and reading books accounting for $(86.7 \%)$ and $(42.9 \%)$ respectively (Table 1 ).

Participation in EAs were reported by 103 students (42.9\%); $79.6 \%$ and $66.0 \%$ participated in activities inside and outside the campus respectively. Volunteering in health awareness campaigns and medical convoys were the most frequently reported EAs accounting for $(73.8 \%)$ followed by sports activities (20.4\%). Most reported reasons for not participating in EAs were unavailability of time and that most EAs are held far from the place of residence (70.8\% and $55.5 \%$ respectively). The vast majority of the studied students $(83.8 \%)$ think that studying medicine affects their ability to participate in EAs. More than half of the students $(57.9 \%)$ reported that studying medicine is time-consuming, moreover, $45.4 \%$ of the studied group think that studying medicine decreased their ability to participate in EAs and $39.6 \%$ reported that it leads to depression. On the other hand, $45.8 \%$ of study participants think that participation in EAs will not affect their grades (Table 2). Nearly one-third $(32.9 \%)$ of the study group reported practicing regular physical activity and the most reported type of activity was aerobics and gymnastics(41.8\%) followed by walking and running $(22.8 \%)$ and football playing (16.6\%) (Results not tabulated).

Concerning the change in free time and its activities; there was a statistically significant difference between free time in high school and free time in faculty as free time was longer during high school ( $p$ value $<0.001)$. Also, there was a difference between family time during high school and during faculty; being longer in high school compared to faculty(pvalue $<0.001)$. By comparing participation in EAs before and after faculty entry, 66 $(27.5 \%)$ of students who reported participation in EAs during faculty were 
not engaged in activities during high school and the difference was statistically significant. Comparison between visiting relatives before and after faculty admission revealed a statistically significant difference as students reported visiting their relatives in lower frequencies after faculty entry (p-value $<0.001$ ) (Table $3)$.

Life satisfaction total score among the studied sample ranged from 2 to 5 with a mean of $4.0 \pm 0.73$. Half of the students $(50.8 \%)$ had a medium level of life satisfaction compared to $24.6 \%$ who had a low and high level of LS. Among different subscales, the highest score was for the friend domain with a mean of $4.41 \pm 0.89$ (2-6) and the lowest score was for the living domain with a mean of 3.72 $\pm 0.78(1.4-5.6)$. Females and physically active students significantly reported higher overall LS scores $(p=0.04$ and $\mathrm{p}=0.01$ respectively). (Table 4 ).

A weak significant negative correlation between internet use during free time and overall LS, family, college and, selfsubscale scores was revealed. Also, selfdomain correlated negatively with hours per day spent in faculty and positively with time spent with family (data not shown)

Extracurricular activities participation was significantly associated with students 'age, academic year, and studying hours. Older students reported more participation in EAs than younger ones. Clinical years students represented $62.1 \%$ of students participating in EAs $(\mathrm{OR}=2.76,95 \%$ $\mathrm{CI}=1.63-4.69$ ). (Table 5).

Multiple linear regression analysis was done to explain and explore variables that might affect LS among the studied sample. For an explanation of variation in LS, different socio-demographic variables were tested including age, sex, and living with whom. Also, educational variables and variables related to EAs and physical activities were tested. By excluding variables that might not affect LS (depending on $\mathrm{R}^{2}$ ), female gender, living alone, being physically active, spending less free time on the internet not for a studying purpose, spending more time with family, and in studying explain about $15 \%$ of the variation in life satisfaction $\left(\mathrm{R}^{2}\right.$ $=0.149, \mathrm{~F}=2.43, \mathrm{P}<0.01)$ (Table 6).

\section{Discussion}

The current study investigated the relationship between LS and EAs participation and time spent with family among a group of medical students in a governmental university to evaluate the impact of participation in EAs on LS and academic achievement as well to compare free time spent with family and relatives during high school and faculty. To our knowledge, this is the first study that tackles these issues among medical students in Egypt. Prior research conducted by Antaramian et al., 2008 among a group of adolescents in the US revealed that overall LS had a mean score of 4.72, this result is somewhat higher than the overall mean LS reported by the current study participants (4.0). Similarly, adolescents reported high satisfaction among friends and self domains with means greater than 5 for both. However medical students in the current study reported lower friend satisfaction and selfsatisfaction accounting for (4.34) and (4.02) respectively. This may be due to differences in age group and faculty experience which is more challenging than school experience. Moreover, living environment satisfaction scores were highest among adolescents in intact families, followed by adolescents in reconstituted families, but the lowest scores were observed among adolescents in single-parent families. However, these differences were not significant. In the current study, students had the highest score in almost all domains if they lived 
alone compared to those living with parents or relatives but the difference showed no statistical significance. This may be due to the higher value that university students put on independence and autonomy as life needs and interests change with age. ${ }^{30}$

Multiple linear regression analysis was done to explain and explore variables that might affect LS among the studied sample. Female gender, living alone, being physically active, spending less free time on the internet not for a studying purpose, spending more time with family, and in studying explain about $15 \%$ of the variation in life satisfaction $\left(\mathrm{R}^{2}=0.149, \mathrm{~F}=2.43\right.$, $\mathrm{P}<0.01)$.

The current study findings agreed with multiple studies that aimed to estimate the association of physical activity with LS, which showed that physical activity increased the odds for higher life
satisfaction.

In the present study, $42.9 \%$ of the study group reported participation in EAs. This finding is much lower than the values reported in other studies by western nonmedical university students. Roulin and Bangerter (2013) pointed out that among 66 undergraduate and postgraduate business and economics students in French-speaking Swiss Universities, 94\% actively participated in EAs. ${ }^{34}$ Similarly, Thompson et al.,2013 study revealed that $87 \%$ of undergraduate student sample $(n=67)$ in UK faculties of science and technology, arts and social sciences and management reported participation in EAs. ${ }^{18}$ In Al - Ansari et al., 2015 study that included students from Alexandria and Dammam dental faculties $(n=199$ and $\mathrm{n}=146$ respectively) EAs participation was $27.1 \%$ and $43.8 \%$, respectively among the studied group. ${ }^{15}$ Higher students' participation in EAs $(73.5 \%, n=183)$ was revealed in a cross-sectional study performed among first to fourth-year medical students in Saudi Arabia. Another study conducted among pre-clinical medical students at Alfaisal University $(n=237)$ showed that $60.3 \%$ participated in EAs. ${ }^{35,36}$ Differences in the findings between all the previously cited researches and the current study findings may be attributed to different academic disciplines and cultural factors.

The current study showed that participation in EAs activities does not have a significant influence on LS. Similarly, Almalki et al., 2017 reported that EAs participation was not significantly associated with burnout levels among Saudi medical students. However, per the same study leading and organizing EAs might result in lower levels of burnout. ${ }^{35}$ This finding contradicts a previous study with high school students where students who engaged in multiple EAs reported a subjective feeling of well-being. ${ }^{37}$ The depth of involvement in EAs seems to have more value as it gives the students a greater opportunity to improve their leadership skills, which may positively affect their academic performance. In the present study, EAs were not significantly associated with academic achievement and this may be due to the fact that there was no question assessing the depth of engagement in EAs. Moreover, the connection between EAs participation and academic accomplishment remains an endless topic of controversy without reliable conclusions. ${ }^{36}$

In the study of pre-clinical medical students at Alfaisal University, the top barrier towards engagement in EAs was "lack of time" $(61.2 \%, n=145) .{ }^{36}$ Similarly, lack of time was considered as the most important barrier to engage in EAs in a study among dental students from Egypt and Saudi Arabia. ${ }^{15}$

This finding agrees with the current study that showed that lack of time was the highest reason $(70.8 \%)$ for not 
participating in EAs as reported by the studied students. Furthermore, clinical phase students' participation in EAs in the current study was significantly higher than the preclinical phase students. This may be explained by the experience gained by students in the early years of studying at the faculty on how to manage their time, in addition to increasing contact time with patients makes the students want to volunteer in more community awareness services and medical convoys as they realize that a lot can be done to help their community.

In summary, this study has identified several significant factors that affect LS and participation in EAs among a group of medical students. The study results can help designing interventions to encourage students to increase their physical activity and to spend less free time surfing the internet thus significantly promoting life satisfaction. Furthermore, the results can help in integrating EAs in the design of the medical curriculum and in planning student support services to enhance the students' quality of life so that students might obtain the best out of their EAs for their personal development, future career, and psychological health. As the present study was applied to a limited group of undergraduate medical students at one governmental university in Cairo careful interpretation of the study results is crucial. Additional research is needed with university student populations from different faculties including private as well as governmental universities.

Conclusion: Female gender, living alone, being physically active, spending less free time on the internet, not for a studying purpose, spending more time with family, and in studying explain the variation in the life satisfaction among medical students.
Recommendations: Emphasizing the importance of identification of modifiable factors that promote life satisfaction among future doctors. Awareness campaign about the benefits of physical activity and the hazards of the internet is important for overall LS and quality of life among them.

Study Limitations: The limited power of cross-sectional design to determine the temporal relationship of LS with various risk factors. In addition, the sample size was relatively small. Furthermore, the current study addresses medical students in one of the famous faculties in the capital city, further studies should be conducted to involve students from different universities and compare LS between students from different faculties.

Consent for publication: "Not applicable"

Funding: This work didn't receive any financial support.

Disclosure statement: The authors have no competing interests.

Data Availability Statement: The datasets generated during the current study are available on request.

Acknowledgment: We express our appreciation to the students who agreed to share in the current study.

\section{References}

1. Eid, M., \& Larsen, R. J. . The science of subjective well-being. New York: Guilford(2008).

2. Diener, E. Subjective well-being. Psychological Bulletin. 1984;95, 542-575. http://dx.doi.org/10.1037//00332909.95.3.542.

3. Fareeda S. A study of life satisfaction and optimism in relation to psychological wellbeing among working and non-working women. International Journal of Education and Psychological Research. 2015;4(4): 81-5.

4. Veenhoven R. A comparative study of satisfaction with life in Europe. Budapest: Eötvös University Press; 1996.

5. Bailey, T. C., Eng, W., Frisch, M. B., \& 
Snyder, C. R. Hope and optimism as related to life satisfaction. The Journal of Positive Psychology, 2007,2, 168-75. http://dx.doi.org/10.1080/174397607014095 46

6. Russel, J. E. A. Promoting subjective well-being at work. Journal of Career Assessment, 2008; 16, 117-31. http://dx.doi.org/10.1177/106907270730814 2.

7. Huebner, E. S., Hills, K. J., Siddall, J., \& Gilman, R. Life satisfaction and schooling. In M. Furlong, R. Gilman, \& E. S. Huebner (Eds.), 2014; Handbook of positive psychology in the schools (2nd ed.). New York, NY: Routledge.

8. Diseth, A., Danielsen, A. G., \& Samdal, O. A path analysis of basic need support, selfefficacy, achievement goals, life satisfaction and academic achievement level among secondary school students. Educational Psychology,2012; 32(3), 335-54. http://dx.doi.org/10.1080/01443410.2012.65 7159.

9. Martin, K., Huebner, E. S., \& Valois, R. F. Does life satisfaction predict victimization experiences in adolescence? Psychology in the Schools, 2008; 45, 705-14. http://

10. dx.doi.org/10.1002/pits.20336.

11. Chow, H. P. Life satisfaction among university students in a Canadian Prairie city: a multivariate analysis. Social Indicators Research,2005; 70, 139-50. http://dx.doi.

12. org/10.1007/s11205-004-7526-0.

13. Rode, J. C., Arthaud-Day, M. L., Mooney, C. H., Near, J. P., Baldwin, T. T., Bommer, W. H., \& Rubin, R. S. Life satisfaction and student performance. The Academy of Management Learning and Education,2005, 4 , 421-33. http://dx.doi.org/10.5465/AMLE.2005.19086 784.

14. Gilman, R., \& Huebner, E. S. Characteristics of adolescents who report very high life satisfaction. Journal of Youth and Adolescence,2006; 35, 311-19. http://dx.doi. 15. org/10.1007/s10964-006-9036-7.

16. Huebner, E. S. Preliminary development and validation of a multidimensional life satisfaction scale for children. Psychological Assessment, 1994; 6(2), http://dx.doi.org/10.1037/1040-

3590.6.2.149

17. Fares J, Saadeddin Z, Al Tabosh H, Aridi H, El Mouhayyar C, Koleilat MK, Chaaya M , El Asmar K. Extracurricular activities associated with stress and burnout in preclinical medical students. J Epidemiol Glob Health. 2016;6(3):177-185

18. Al-Ansari A, Al-Harbi F, AbdelAziz W, AbdelSalam M, El Tantawi MM, El Refae I. Factors affecting student participation in extra-curricular activities: A comparison between two Middle Eastern dental schools. Saudi Dent J. 2016;28(1):36-43.

19. Astin A, Sax L, Avalos J. Long-term effects of volunteerism during the undergraduate years. Rev High Ed. 1999; 22(2):187-202.

20. Veronesi, M.C., Gunderman, R.B.. Perspectives: the potential of student organizations for developing leadership: one school's experience. Acad. Med. 2012; 87 (2), 226-29.

21. Thompson, L.J., Clark, G., Walker, M., Duncan Whyatt, J. 'It's just like an extra string to your bow': exploring higher education students' perceptions and experiences of extracurricular activity and employability. Act. Learn. High Educ. 2013;14 (2), 135-147.

22. Miller, K.E., Melnick, M.J., Barnes, G.M., Farrell, M.P., Sabo, D. Untangling the links among athletic involvement, gender, race and adolescent academic outcomes. Soc. Sport J. 2005;22 (2), 178-93.

23. Derous, E., Ryan, A.M. When earning is beneficial for learning: the relation of employment and leisure activities to academic outcomes. J. Vocat. Behav. 2008;73, 118-31.

24. Baker, C.N. Under-represented college students and extracurricular involvement: the effects of various student organizations on academic performance. Soc. Psychol. Educ. 2008; 11, 273-98.

25. Coria M.D, Rivera N.G, Sepúlveda H.E, Jara C.G, Sepúlveda J.A, Schnettler B, Urra O.V, ValenzuelaP.S. Life Satisfaction in Chilean University Students: An Examination of the Relation between Gender and Socioeconomic Level, 2017; Psico, 11(1), 4055. http://dx.doi.org/10.21615/ cesp.11.1.4 
26. Cao.H, Sun.Y, Wan.Y, Jiahu Hao. J and Tao.F. Problematic Internet use in Chinese adolescents and its relation to psychosomatic symptoms and life satisfaction . BMC Public Health 2011; 11:802 http://www.biomedcentral.com/14712458/11/802

27. Kozar, Joy M. and Marcketti, Sara B., "Using the Multidimensional Students' Life Satisfaction Scale to Examine the Psychological Wellness of Today's Undergraduate Students" (2007). Apparel, Events and Hospitality Management Conference Proceedings and Presentations. 37. http://lib.dr.iastate.edu/aeshm_conf $/ 37$

28. Galíndez, E., \& Casas, F. Adaptation and validation of the MSLSS of multidimensional life satisfaction with a sample of adolescents. Revista de Psicología Social,2011, 26, 30923.

http://dx.doi.org/10.1174/0213474117973612 84

29. Huebner, E. S., \& Gilman, R. An introduction to the Multidimensional Student's Life Satisfaction Scale. Social Indicators Research, 2002, 60, 115-22. http://dx.doi.org/10.1023/A:1021252812882

30. Huebner, E. S. Manual for the Multidimensional Student's Life Satisfaction Scale. University of South Carolina, 2001.

31. Sawatzky, R., Ratner, P. A., Johnson, J. L., Kopec, J. A., \& Zumbo, B. D. . Sample heterogeneity and the measurement structure of the Multidimensional Students' Life Satisfaction Scale. Social Indicator Research, 2009, 94, 273-96. DOI: 10.1007/s11205-0089423-4

32. Cohen J, Cohen P, West S, Aiken L. Applied Multiple Regression-Correlation Analysis for the Behavioral Sciences. 2003, NJ: Lawrence Erlbaum Associates

33. Antaramian, S., Huebner, S., \& Valois, R. Adolescent life satisfaction. Applied
Psychology 2008 : An International Review, 57, 112-126.

34. Pengpid S, Peltzer K. Sedentary Behaviour, Physical Activity and Life Satisfaction, Happiness and Perceived Health Status in University Students from 24 Countries. Int J Environ Res Public Health. 2019;16(12):2084. Published 2019 Jun 13. doi:10.3390/ijerph16122084

35. Grant N, Wardle J, Steptoe A. The relationship between life satisfaction and health behavior: a cross-cultural analysis of young adults. Int $J$ Behav Med. 2009;16(3):259-268. doi:10.1007/s12529009-9032-x

36. Parkerson GR Jr, Broadhead WE, Tse CK. The health status and life satisfaction of firstyear medical students. Acad Med. 1990;65(9):586-588. doi:10.1097/00001888199009000-00009

37. Roulin, N., Bangerter, A. Students' use of extra-curricular activities for positional advantage in competitive job markets. J. Educ. 2013; 26 (1), 21-47.

38. Almalki SA, Almojali AI, Alothman AS, Masuadi EM, Alaqeel MK. Burnout and its association with extracurricular activities among medical students in Saudi Arabia. Int J Med Educ. 2017;8:144-150. doi:10.5116/ijme.58e3.ca8a

39. Almasry M, Kayali Z, Alsaad R, Alhayaza G, Ahmad M.S, Obeidat A, Abu-Zaid A. Perceptions of preclinical medical students towards extracurricular activities. Int $\mathrm{J}$ Med Educ.2017, 8:285-89. doi:10.5116/ijme.5973.297a

40. Palen LA, Coatsworth JD. Activity-based identity experiences and their relations to problem behavior and psychological wellbeing in adolescence. J Adolesc. 2007;30(5):721-737.

doi:10.1016/j.adolescence.2006.11.003 